\title{
New findings of the Oslo region erratics in glaciofluvial deposits of NW Poland
}

\author{
Ewelina Lipka ๑
}

Institute of Geoecology and Geoinformation, Adam Mickiewicz University in Poznan, Poland, e-mail: e.lipka@amu.edu.pl

\begin{abstract}
Glacial erratics of the Oslo region are only occasionally found in Poland. This is because the Norwegian Channel ice stream did not reach this area. Recently a few specimens of rocks representing Oslo region have been found at the Owczary site (north-western Poland), what raised questions regarding the relative age of the deposits, as well as the depositional history of the erratics. The questions were addressed using lithofacies analysis, as well as structural and textural analyses, combined with clast petrography (medium and coarse gravel). Clast petrography analysis revealed that the deposits containing rocks of the Oslo region are of the late Saalian age (Warthe), though some evidence suggest the early Saalian age (Drenthe).

Key words: Oslo rhomb porphyry, Oslo basalt, clast petrography, indicator erratics, Saalian glaciation
\end{abstract}

\section{Introduction}

Glacial erratics (rocks transported by the glacial ice) of the Oslo region are rarely found in glacial deposits of north-western (NW) Poland. The vast majority of indicator and statistical erratics points to southern and middle Sweden, the Baltic Sea basin, south-western Finland and Denmark (Górska 2000, Górska-Zabielska 2008, Czubla 2001, Lipka 2011). This is in accordance with Stokes and Clark (2001, see also Punkari, 1997), who claim that the Baltic Sea Ice Stream (B) was the most important in terms of its impact on the southern sector of the Scandinavian Ice Sheet, although the Norwegian Channel Ice Stream (A) is also thought to have played an important role during the last glaciation. This particular area of NW Poland was predominantly under the influence of one of the branches of the Baltic Sea ice stream - B3 (Punkari 1997, Stokes, Clark 2001; Fig. 1A).

Indicator erratics are glacial erratics that are relatively easy to recognize macroscopically and derive from a single source area. There are several indicator erratics deriving from the Oslo region (Schulz 1973, 2003, Zandstra 1999, Smed/Ehlers 2002). Probably the most distinctive are Oslo porphyries: both Oslo rhomb porphyry or Oslo rectangle porphyry and Oslo basalt. The other specific rocks are syenites and monzonites: nordmarkit and larvikite. Also ekerite (a quartz syenite) and Drammen granite are quite widespread. The only one sedimentary rock originating from the Oslo region is Oslo rhomb porphyry conglomerate, which is very rare. Oslo rhomb porphyry, the most characteristic indicator erratic among the Oslo region rocks, owes its name to the outstanding elongate rhombic shape of feldspar (anorthoclase) phenocrysts, $1-2 \mathrm{~cm}$ long on average, up to $4 \mathrm{~cm}$. Feldspar crystals are light grey when fresh, turning white or brownish when weathered, standing out from the fine-grained to homogeneous, brownish-grey to violet-brown matrix (Hesemann 1975). The overall appearance of the rock makes it easy to recognise.

Oslo region erratics are generally typically found all over the area between north and west Jutland, the Netherlands and eastern Great Britain: from Yarmouth to Banff (Schulz 1973). Any reports of the Oslo region erratics found in Poland are extraordinary and considered beyond the regular extent, especially directly within glacial or glaciofluvial deposits (other possibilities, including ship transport - as ballast stones, have been reported though - see Górska 2003). There are only 20 localities in NW Poland and Brandenburg (eastern Germany), where Oslo region erratics have been reported since late XIXth century. According to Schulz (1973) - the eastern 


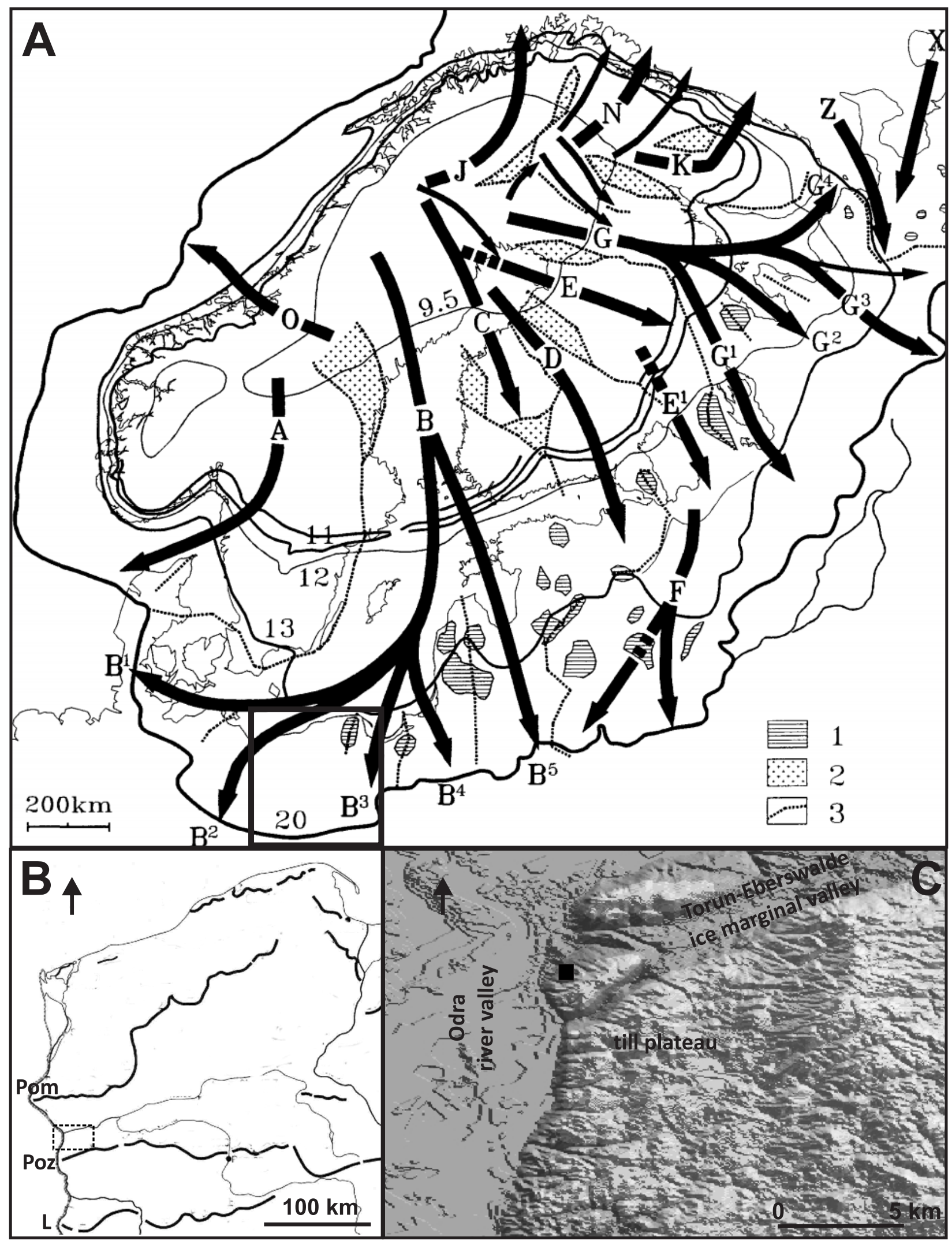

Fig. 1. Location of the study site

A - Ice streams of the last Scandinavian Ice Sheet according to Punkari (1997). Ice streams - arrows, interlobate uplands (1), other interstream/interlobate areas (2), interlobate joints (3). The black square marks the location of the Owczary site (area depicted in part B); B - Location of the Owczary site in NW Poland with ice margin limits during the particular phases of the last glaciation: L - Leszno Phase, Poz - Poznan Phase, Pom - Pomeranian Phase. Black rectangle (dashed line) marks the location of the area covered by the Digital Elevation Model (DEM); C - DEM of the Owczary site area (black square indicates the location of the study site) 
extent of the Oslo region erratics was greatest during Drenthe glaciation (the early Saalian), while during Warthanian (late Saalian) glaciation the whole Oslo erratics appearance 'plume' (German: Geschiebestreufächer) moved to the west - in the North Sea direction.

A few rocks of the Oslo region were found within glaciofluvial deposits of the Owczary site (Fig. 2). The site is situated in western Poland, in north-western part of the Lubuska Upland. According to SMGPsheet Słubice (Urbański 2005b) and Geological map 1:50 000 sheet Seelow/Kostrzyn nad Odrą (Thieke et al. 2008), it is located on the northern fringe of a till plateau, between Torun-Eberswalde ice-marginal valley in the north and the Oder river valley in the west (Fig. 1C). Its immediate substratum is glacial till (of Vistulian age, according to Geological map 1:50 000 - ground moraine of Brandenburg Phase age - it relates to the Leszno phase, Last Glacial Maximum LGM in western Poland), however there are glaciofluvial sands (the late Saalian age, Urbański 2005b, Thieke et al. 2008) visible to the west and west-northwest as well.

The few specimens of Oslo region erratics were found directly within glaciofluvial deposits, what should provide an unequivocal evidence, but in fact raised further questions regarding the relative age of the deposits, where the Oslo erratics were found, as well as the erratics depositional history. This paper aims at answering these questions.

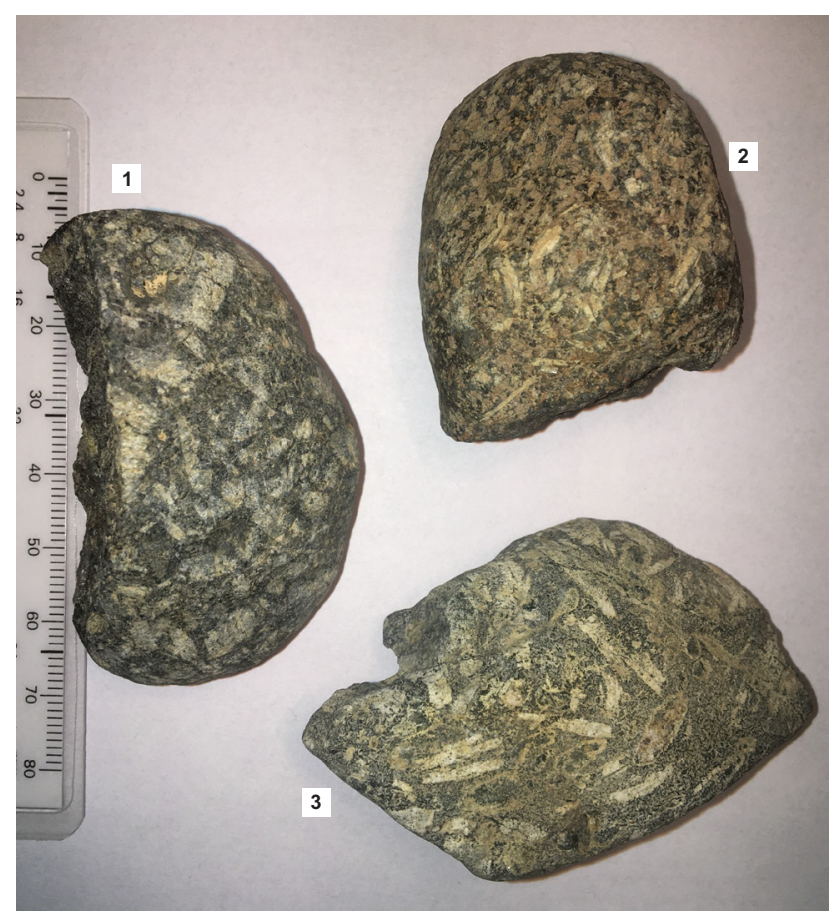

Fig. 2. Erratics of the Oslo region found in glaciofluvial deposits in Owczary site (NW Poland)

1, 2 - specimens of Oslo basalt, 3 - specimen of Oslo rhomb porphyry (see text)

\section{Previous research}

Few clast petrography studies have been carried in Lubuska Upland, NW Poland. Kade (1852) opened this short list, with a statement that some of the crystalline erratics of Międzyrzecz region derive from Scandinavia. Hesemann (1932) stated prevalence of erratics from eastern Scandinavia and lack of Norwegian erratics (this is depicted by the so-called boulder indicator 5230), while in 1937, based on the boulder indicator, Hesemann distinguished Sulechów lobe. In 1934 Milthers, along the Międzychód - Świebodzin - Sulechów line, draws the eastern limit of Norwegian erratics appearance. Krygowski (1948) studied 50-100 mm fraction erratics representing both diamicton and fluvioglacial deposits (i.a. near Łagów, Toporów and Świebodzin). Konieczny (1956), using Milthers' method, divided the erratics into 4 groups: Norwegian, Dalarna, Baltic, and western-Finnish, obtaining results similar to that of Hesemann (1937): prevalence of Finnish and Åland rocks, with no Norwegian representatives.

There is also a numerous group of studies regarding geomorphology and quaternary geology of Lubuska Upland, mentioning clast petrography of surficial deposits. Kozacki (1962) described Pliszka sandur, characterising its clast petrography. Skompski (1981) distinguished stratigraphical units of quaternary deposits in Lubuska Upland, using gravel petrography (5-10 mm). Also Urbański (2007) distinguished 8 types of diamictons in Lubuska Upland, using similar methods. Urbański gives eight lithopetrographic types of diamictons in correlation to diamictons of Greater Poland, Silesia Lowland and vicinity of Szczecin. There is also a group of studies carried by the Polish Geological Institute - National Research Institute in order to develop sheets of detailed geological map of Poland (SMGP) in 1:50 000 scale, particularly the comments to the map sheets reveal much information with regard to clast petrography (e.g. Bartczak 2003, Chachaj 2003, Chmal 2003, Nowak 2003, Sztromwasser 2003, 2005, Multan 2004, Trela 2004, Winnicki 2004, Urbański 2005a, b, Piotrowski, Sochan 2007a, b, Schulz et al. 2007a, b, Thieke and Kowalski 2007, Thieke et al. 2008).

\section{Methods}

In order to recognize lithology and structure of the deposits revealed in Owczary site and address the questions relating to the relative age of the deposits and the Oslo erratics deposition, a suite of methods was employed (for details see Lipka 2011). Here, the reference will be made mainly to clast petrography. 
Lithofacies analysis as well as structural and textural analysis (grain size, $\mathrm{CaCO}_{3}$ content) were applied. Lithofacies analysis was performed in accordance with suggestions of Miall (1977) modified by Zieliński (1992), Maizels (1993) and Pisarska-Jamroży (2008), along with modifications of Krüger and Kjær (1999) relating to diamicton lithofacies.

Clast petrography analysis was employed in two grain size ranges: for medium $5-10 \mathrm{~mm}$ and coarse $20-60 \mathrm{~mm}$ gravels in order to verify the age of the de- posits. Medium gravel petrography analysis followed the Polish Geological Institute indications (for reference see PIG Instruction 1996, Kenig 1998 and Lipka 2011). Also the average petrographic coefficients $\mathrm{O} / \mathrm{K}, \mathrm{K} / \mathrm{W}, \mathrm{A} / \mathrm{B}$ were calculated, where $\mathrm{O}$ - sedimentary rocks, $\mathrm{K}$ - crystalline rocks and quartz, $\mathrm{W}$ - Palaeozoic limestones and dolomites, $\mathrm{A}$ - non-resistant rocks: Palaeozoic limestones, dolomites, Palaeozoic shales, B - resistant rocks: crystalline rocks, quartz, Palaeozoic sandstones.

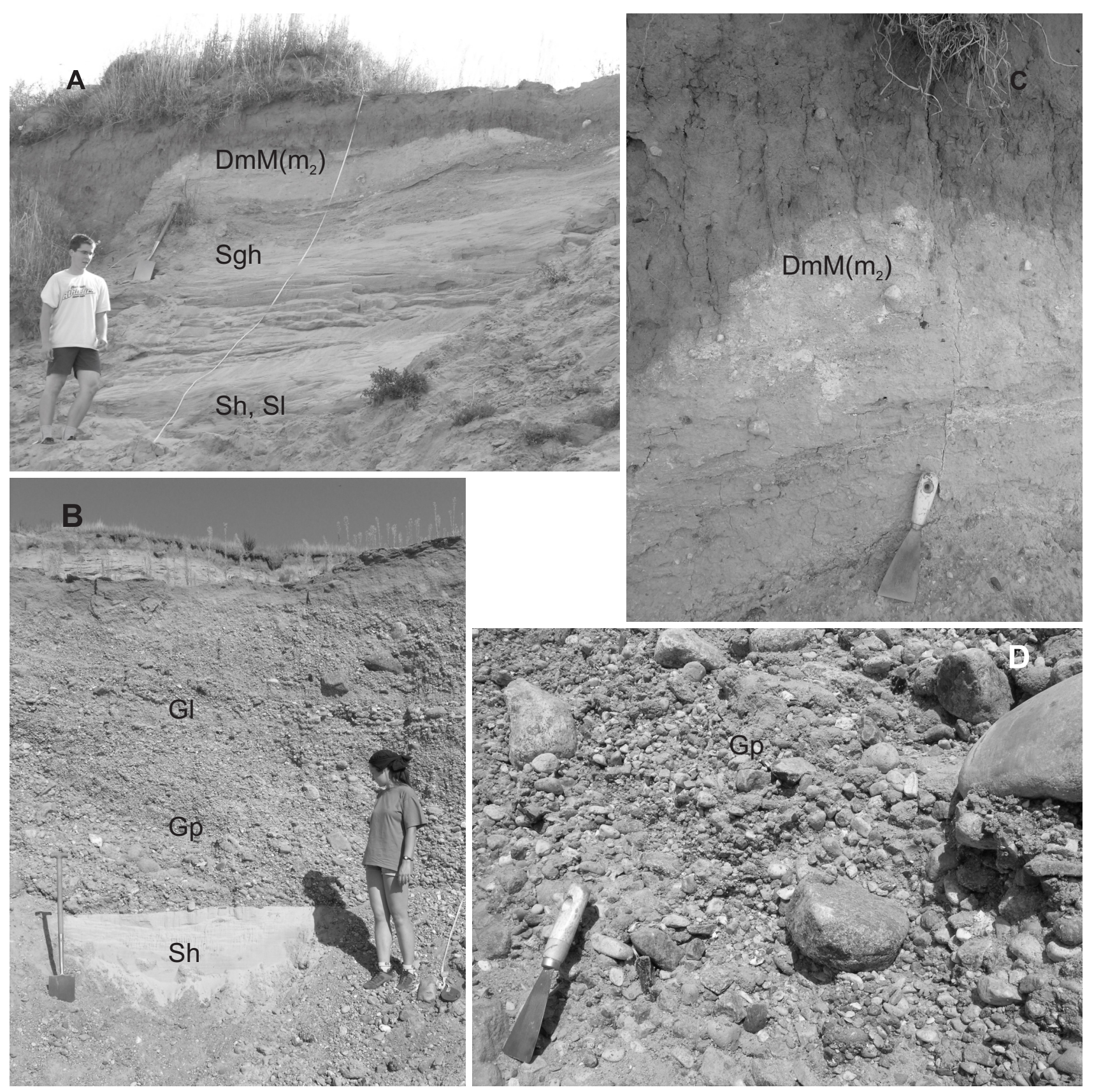

Fig. 3. Lithofacies exposed at the Owczary study site

A - The upper part of the sequence comprising laminated sand (bottom) and massive diamicton (top); B - The lower part of the sequence comprising laminated sand (bottom) overlain by cross-bedded gravel (top); C - The massive top diamicton, with weak stratification visible in the bottom part and decalcification in the top part; D - The cross-bedded gravel bed in the lower part of the sequence, with many coarser clasts (MPS $12 \mathrm{~cm}$ ), high angle cross-bedding, near to angle of repose and low angle cross-beds in the upper part, separated by a reactivation surface. Oslo region erratics were found in this deposit. Lithofacies code symbols - see explanation in text 
Indicator and statistical erratics analysis was performed for coarse gravel $(20-60 \mathrm{~mm}$, ca 1000 specimens in one sample), following the method of Górska-Zabielska (Górska 2000, Górska-Zabielska 2008), based on Lüttig (1958), Meyer (1983), Smed (1993) and Vinx (1993). Based on the indicator erratics spectrum, the so-called theoretical boulder center TBC (German: TGZ - Theoretisches Geschiebezentrum) was calculated (Lüttig 1958). The results of the analysis were depicted using the so-called circle-maps (Smed 1993) - maps of Scandinavia, where all indicator erratics are presented as circles in respective source areas. The diameter of the circle is proportional to the percentage of recognized specimens. TBC is also depicted in circle maps.

\section{Results}

Geological succession of the Owczary setting is visible in section hundreds of metres long and dozens of metres high, as sand and gravel is excavated in this gravel pit. The southern wall of the pit, reaching 24 $\mathrm{m}$ deep below the ground surface is described here (Fig. 3A and B, 4A), in two profiles: 4 (Fig. 3B) and 6 $\mathrm{m}$ (3A) high (due to safety measures).

The sediment profile consists of four main lithofacies (Fig. 3, 4A). The first one is fine, well-sorted, white, horizontally laminated sand (Sh). An angular discordance separates the first lithofacies (Fig. 3B bottom) from the second one, which is a 2,5-meter thick cross-bedded gravel bed (Fig. 3B - top and 3D),

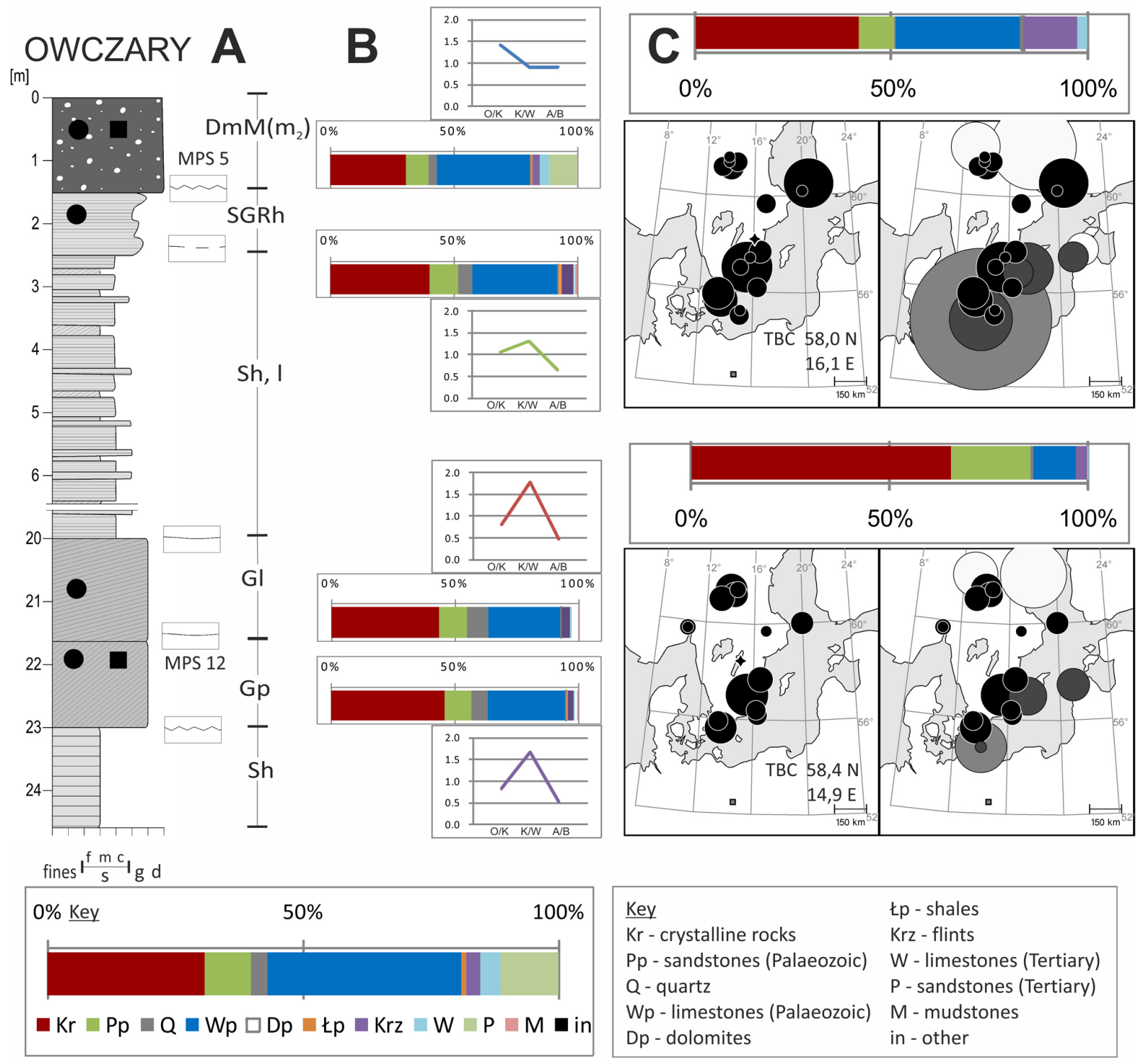

Fig. 4. Owczary site

A - Simplified lithological log of the deposits exposed at Owczary. Black circles - samples for clast petrography (5-10 mm), black squares - samples for clast petrography $(20-60 \mathrm{~mm})$ and indicator erratics analysis; B - Results of clast petrography analysis (5-10 $\mathrm{mm})$. Bar graphs show clast composition, line graphs show petrographic coefficients; C - Results of clast petrography analysis (20-60 $\mathrm{mm}$ ) and indicator erratics analysis. Bar graphs show clast composition, circle maps show indicator erratics spectra and TBC (left) and statistical erratics spectra (right) 
containing many coarse clasts (MPS - maximum particle size $-12 \mathrm{~cm}$ ). Its lower part exhibits high angle planar cross-bedding (near to angle of repose) - Gp, whereas the upper part has low angle cross-beds Gl. They are separated by a reactivation surface. The upper part of this profile was impossible to identify and describe due to a colluvium cover. Higher in the profile above (Fig. 3A), there is a $4 \mathrm{~m}$ thick series of pale, medium-grained sand (Fig. 3A - bottom), intercalated with coarse-grained sand and - in places fine, horizontally laminated (occasionally low-angle) sand Sh, Sl. The sand changes over to $60 \mathrm{~cm}$ thick horizontally laminated coarse sand with gravel (SGh) (reverse grading). Above this, up to the ground surface, there is a brownish layer of massive matrix-supported diamicton (Fig. 3A - top and 3C), with medium-grained (silty and sandy) matrix and moderate number of clasts $\operatorname{DmM}\left(\mathrm{m}_{2}\right)$, and MPS $50 \mathrm{~mm}$. The top darker part of the diamicton (40 cm thick) is weathered - what manifests mainly by decalcification, both in weak reaction with $\mathrm{HCl}\left(\mathrm{CaCO}_{3}\right.$ below 1\%) and lack of carbonate clasts (Fig. 4B).

\section{Clast petrography and indicator erratics}

\section{Bottom glaciofluvial deposits}

The analysis of clast (coarse gravels: $20-60 \mathrm{~mm}$ ) petrography revealed (Fig. 4C) distinct predominance of crystalline rocks $\mathrm{Kr}$ (almost 66\%). Palaeozoic sandstones Pp share 20\%, Palaeozoic limestones Wp share ca $10 \%$, flints $\mathrm{Krz}$ gain almost $3 \%$, whereas quartz Q and Cretaceous limestones $\mathrm{W}-$ less than $1 \%$. Neither Palaeozoic shales Łp nor dolomites Dp were observed within this fraction.

When indicator erratics spectrum (Fig. 4C) of bottom glaciofluvial deposits is taken into account, the rocks of Småland region have the greatest contribution (39\%). These are mainly Småland granite (with distinctive blue quartz crystals) and Västervik quartzite. Over $31 \%$ share rocks of Dalarna region, mainly porphyries, with easily recognisable Bredvad porphyry. Over $17 \%$ take rocks of Skane-Blekinge-Bornholm region (mainly sedimentary rocks of Skane: Hardeberg and Höör sandstones). Around $6 \%$ share rocks of Åland Isles (Åland granite) and almost $2 \%$ share rocks of Upland region.

A few rocks of Oslo region were found as well unexpectedly, as rocks of Oslo region are very rarely found in Poland (compare Schulz 1973). Two specimens of Oslo basalts and one Oslo rhomb porphyry were recognised (Fig. 2).

Among statistical erratics, red Baltic sandstones (originating from Swedish coast directly to the east of Dalarna or the Kalmar Strait alternatively) have
$5 \%$ share, whereas violet Dalarna sandstones $2 \%$. Over $1 \%$ share of red Ordovician limestones (western part of the Baltic Sea basin), and the same share of pelitic limestones from eastern part of the Baltic Sea basin is also remarkable.

\section{Upper diamict}

Clast composition (coarse gravels: $20-60 \mathrm{~mm}$, Fig. 4C) of the upper diamict is dominated by crystalline rocks (>41\%). Palaeozoic limestones share ca. 32\%, sandstones nearly $9 \%$. Flints gain remarkable $13.6 \%$, whereas Cretaceous limestones nearly 3\% (Cretaceous limestones and flints share the same source area in western part of the Baltic Sea, but flints are notably more resistant than Cretaceous limestones). There is only a slight share (below 1\%) of dolomites (source area in eastern Baltic Sea) and quartz.

The spectrum of indicator erratics in the upper diamict differs visibly from the deposits below (Fig. 4C), with rocks of Småland region dominating (nearly $36 \%$ ) and rocks representing the region of Skåne, Blekinge and Bornholm taking the second place (mainly sedimentary rocks, but also Bornholm granite). Nearly 24\% rocks come from Åland (Åland granite, Åland rapakivi granite, Åland quartz porphyry). The remainder of indicator erratics represent regions of Dalarna (nearly 12\% - Dalarna porphyries) and Upland (nearly 4\% - black and white Uppsala granite).

Statistical erratics in the upper diamict are represented (a few percent each) mainly by sandstones of northern Sweden (violet Dalarna sandstones) and the Baltic Sea (red Baltic sandstones). The share of red Palaeozoic limestones is also visible, as well as Palaeoporella limestones - both types of limestone represent western part of the Baltic Sea.

In addition, the so-called theoretical boulder centre TBC was calculated for every coarse-gravel sample. TBC for glaciofluvial deposits value is $\left(58.4^{\circ} \mathrm{N}\right.$, $14.9^{\circ} \mathrm{E}$ ) and is located to the West comparing to TBC for younger upper diamict $\left(58^{\circ} \mathrm{N}, 16.1^{\circ} \mathrm{E}\right)$ (Fig. $\left.4 \mathrm{C}\right)$.

\section{Gravel petrography}

There is a dichotomy visible between gravel composition $(5-10 \mathrm{~mm})$ of the bottom fluvioglacial deposit and the upper diamicton (Fig. 4B). Gravel petrography of the fluvioglacial deposit shows a remarkable prevalence of crystalline rocks over Palaeozoic limestones and a significant share of sandstones - ca $10 \%$. The remaining rocks are: quartz grains (5-9\%), flints (1-5\%) -deriving from the western part of the Baltic Sea, Palaeozoic shales (southern part of the Baltic Sea) - ca $2 \%$, local sandstones with $2.2 \%$ share, mudstones $-1.2 \%$. Apart from the fact that local limestones (Cretaceous) as well as dolomites do not exceed 
$1 \%$ share, this marginal amount of dolomites found in fluvioglacial deposit is worth noticing, as not a trace of dolomites (deriving from the eastern part of the Baltic Sea) was found in the diamict above.

The average petrographic coefficients calculated for the bottom part of the fluvioglacial set are: $\mathrm{O} /$ $\mathrm{K}=0.81, \mathrm{~K} / \mathrm{W}=1.74, \mathrm{~A} / \mathrm{B}=0.48$ and are only slightly different from the top part of the fluvioglacial set: $\mathrm{O} /$ $\mathrm{K}=1.13, \mathrm{~K} / \mathrm{W}=1.21, \mathrm{~A} / \mathrm{B}=0.69$ (pointing to Saalian glaciation origin).

Palaeozoic limestones, with a significant share of crystalline rocks, (far-travelled) sandstones and quartz (respectively), in turn dominate petrographic composition of the diamict (Fig. 4B). Compared to the fluvioglacial deposit, there is a higher share of Palaeozoic shales and local limestones W. Flints Krz are represented in lower amounts than in the fluvioglacial deposit, while no dolomites were found.

The average petrographic coefficients calculated for the diamicton are: $\mathrm{O} / \mathrm{K}=1.63, \mathrm{~K} / \mathrm{W}=0.89$, A/ $\mathrm{B}=0.81$, and are characteristic for Vistulian deposits.

\section{Interpretation and discussion}

As mentioned above, Oslo erratics in NW Poland seem rather outstanding findings. According to Schulz (1973) - the eastern extent of Oslo erratics was greatest during Drenthe glaciation (early Saalian), while during Warthanian (late Saalian) glaciation the whole Oslo erratics appearance 'plume' (German: Geschiebestreufächer) moved to the west - in the North Sea direction. Moreover, Schulz (1973) found Oslo erratics in Saalian deposits (in the area south of the Last Glacial Maximum, LGM is the line of Leszno phase during Vistulian glaciation) and in Vistulian deposits in NW Poland: Western Pomerania, Lubuska Upland and western Greater Poland. Schulz (1973) also points that ice advance from middle and southern Sweden was longer active in the so-called Oder lobe. There is also the evidence delivered by Lüttig (1958), who performed clast petrography and indicator erratics analysis in Brandenburg, Germany and western Poland. He has not identified any erratics of Norwegian origin (Oslo region erratics among them) in Vistulian deposits. This should point to the incorporation of Oslo erratics into Warthanian till (upper Saalian) from the lower Saalian (Drenthe) till.

Żynda (1967) mentions that in Lubuska Upland area Vistulian glacial till is very thin (up to a few meters) and covers older, relatively shallow glaciotectonised deposits - mainly of late Saalian age (Drenthe). The glaciotectonised older glacial deposits lying under a thin Vistulian sediment cover or reaching the surface were also reported by Lipka (2011).
Górska (2003) reported finding two Oslo rhomb porphyry erratics in NW Poland, on the Wolin island. Unfortunately the stratigraphy of the erratics in unknown, as they were found on an abrasion platform at the foot of a cliff. Taken into account petrographic composition of the lower glacial till bed (Saalian) in the cliff, below which the Oslo erratics had been found, Górska suggested that the two Oslo rhomb porphyries belong to the lower - Saalian - glacial till (distinct NW direction of ice sheet advance, contrary to the upper glacial till). It is worth mentioning that Górska did not reject other possibilities for the Oslo erratics to appear on Wolin island beach - iceberg transport or ship transport - as ballast stones that are not relevant in this case as here the Oslo erratics were found directly within fluvioglacial deposits, ca 20 meters below the surface.

To sum up, petrographic coefficients calculated for the lower part of the sequence (based on 5-10 $\mathrm{mm}$ gravels) at the Owczary site, where Oslo region erratics were found, are distinct from the upper diamicton petrographic coefficients and resemble deposits of upper Saalian (Warthe) stage (Urbański 2005a, b, Thieke et al. 2008 provide petrographic coefficients for the upper Saalian deposits in this region). Based on indicator erratics analysis however (20-60 mm gravels), based on Schulz (1973) significant presence of Åland erratics in the deposits (gravels of the lower part of the sequence) should point to even older deposits - possibly the lower Saalian (Drenthe). As a consequence, it is suggested here that the Oslo erratics were probably incorporated from older deposits (possibly the lower Saalian Drenthe) into the upper late Saalian (Warthe) gravels of glaciofluvial origin.

\section{Summary and conclusion}

The Vistulian glacial till cover in Lubuska Upland area is very thin and covers older, relatively shallow glaciotectonised deposits, reaching the surface in places.

The analyses of the deposits at the Owczary site revealed that the glaciofluvial and glacial deposits at the Owczary site are diverse, with the lower part of the sequence (gravels) distinct from the upper part (diamicton).

Unexpectedly, the Oslo region rocks - very rare finding in NW Poland - were identified in the lower part of the sequence (gravels). Two specimens of Oslo basalt and one specimen of Oslo rhomb porphyry were identified.

Stratigraphic correlation based mainly on medium gravel petrography, suggests that the gravels in the lower part of the sequence at the Owczary site, 
where Oslo region erratics were found, are distinct from the upper diamicton and resemble deposits of upper Saalian (Warthe) stage, while the top part itself (diamicton) is thought to be of Vistulian (LGM: Leszno-Poznań phase) age.

The indicator erratics analysis results however, based on significant presence of Åland erratics in the deposits (gravels of the lower part of the sequence) should point to even older deposits - possibly the lower Saalian (Drenthe).

Based on the indicator erratics analysis, combined with clast petrography, it is suggested here that the Oslo erratics were presumably deposited within the lower Saalian deposits (Drenthe) and were later incorporated into the upper Saalian (Warthe) deposits, forming a layer of gravels of glaciofluvial origin.

\section{Acknowledgements}

The author wishes to thank three anonymous reviewers for their valuable suggestions and comments.

\section{References}

Bartczak E., 2003. Objaśnienia do Szczegółowej mapy geologicznej Polski, arkusz Świebodzin (502). PIG, Warszawa.

Chachaj J., 2003. Objaśnienia do Szczegółowej mapy geologicznej Polski, arkusz Czerwieńsk (537). PIG, Warszawa.

Chmal R.,2003. Objaśnienia do Szczegółowej mapy geologicznej Polski, arkusz Toporów (501). PIG, Warszawa.

Czubla P., 2001. Eratyki fennoskandzkie w Polsce Środkowej i ich znaczenie stratygraficzne. Acta Geographica Lodziensis 80: 174.

Ehlers J. 1990. Reconstructing the dynamics of the North-west european Pleistocene ice sheets. Quaternary Science Reviews 9: 71-83.

Górska M., 2000. Wybrane właściwości petrograficzne vistuliańskich moren dennych środkowej i zachodniej Wielkopolski oraz ich znaczenie dla dynamiki ostatniego lądolodu. Prace Komisji Geograficzno-Geologicznej PTPN 26: 145.

Górska M., 2003. Nowe znaleziska narzutniaków porfiru rombowego z Oslo na terenie północno-zachodniej Polski. Przegląd Geologiczny 51: 580-585.

Górska-Zabielska M., 2008. Fennoskandzkie obszary alimentacyjne osadów akumulacji glacjalnej i glacjofluwialnej lobu Odry. Wydawnictwo Naukowe UAM.

Hesemann J., 1932. Zur Geschiebeführung und Geologie des Odergletschers. I Äusere Rosenthaler und Velgaster Randlage. Jahrbuch der Preußische Geologische Landesanstalt 53.

Hesemann J., 1937. Zur Geschiebeführung Und Geologie des Odergletchers. II Der Züllichauer Bogen. Jahrbuch der Preußische Geologische Landesanstalt 58.

Hesemann J., 1975. Kristalline Geschiebe der nordischen Vereisungen. Geologisches Landesamt Nordrhein-Westfalen.

Instrukcja opracowania i wydania Szczegółowej mapy geologicznej Polski w skali 1: 50 000, 1996. Państwowy Instytut Geologiczny, Warszawa: 1-127.

Kade M., 1852. Die losen Versteinerungen des Schanzenberges bei Meseritz. Meseritz.

Kenig K., 1998. Nowe ujęcie petrograficznych podstaw stratygrafii glin morenowych w Polsce północno-wschodniej. In: S. Lisicki, L. Marks, J. Medek, K. Pochocka (eds), Nowe jednostki stratygraficzne Pojezierza Mazurskiego - V Konferencja „Stratygrafia plejstocenu Polski”, Komitet Badań Naukowych, Komisja Badań
Czwartorzędu PAN, PIG, Instytut Geologii Podstawowej UW, Iznota: 10-11.

Konieczny S., 1956. Z badań nad rozmieszczeniem eratyków krystalicznych zlodowacenia plejstoceńskiego w Zachodniej Polsce. Prace Komisji Geograficzno-Geologicznej PTPN 2(1): 1-42.

Kozacki L., 1962. Sandr Pliszki i jego zasoby wodne. Master thesis, Adam Mickiewicz University in Poznań.

Krüger J., Kjær K., 1999. A data chart for field description and genetic interpretation of glacial diamicts and associated sediments - with examples from Greenland, Iceland and Denmark. Boreas 28: 386-402.

Krygowski B., 1948. Z badań nad narzutniakami Ziem Zachodnich. Badania Fizjograficzne nad Polską Zachodnią 1: 48-57.

Lipka E., 2011. Zróżnicowanie cech petrograficznych osadów polodowcowych na Wysoczyźnie Lubuskiej. Ph.D. thesis, Adam Mickiewicz University in Poznań.

Lüttig G., 1958. Methodische Fragen der Geschiebeforschung. Geologisches Jahrbuch 75: 361-418.

Maizels J.K., 1993. Lithofacies variations within sandur deposits: the role of runoff regime, flow dynamics and sediment supply characteristic. Sedimentary Geology 85: 299-325.

Meyer K.-D., 1983. Indicator pebble and stone count methods. In: J. Ehlers (ed), Glacial deposits in North-West Europe. A. A. Balkema, Rotterdam: 275-287.

Miall A.D., 1977. A review of the braided river depositional environment. Earth Science Reviews 13: 1-62.

Milthers V., 1934. Die Verteilung skandinavischer Leitgeschiebe im Quartär von Westdeutschland.

Multan M., 2004. Objaśnienia do Szczegółowej mapy geologicznej Polski 1:50 000, arkusz Krzeszyce (426). PIG, Warszawa.

Nowak J., 2003. Objaśnienia do Szczegółowej mapy geologicznej Polski 1:50 000, arkusz Sulechów (538). PIG, Warszawa.

Piotrowski A., Sochan A., 2007a. Objaśnienia do Szczegółowej mapy geologicznej Polski 1:50 000, arkusze Seelow (423) i Kostrzyn (424). PIG, Warszawa.

Piotrowski A., Sochan A., 2007b. Objaśnienia do Szczegółowej mapy geologicznej Polski 1:50 000, arkusz Słońsk (425). PIG, Warszawa.

Pisarska-Jamroży M., 2008. Mechanizmy depozycji w strefie glacimarginalnej zlodowacenia Wisły. Studium sedymentologiczne z Pomorza Zachodniego i Jutlandii. Wydawnictwo Uniwersytetu Kazimierza Wielkiego, Bydgoszcz: 1-163.

Punkari M., 1997. Glacial and glaciofluvial deposits in the interlobate areas of the Scandinavian Ice Sheet. Quaternary Science Reviews 16: 741-753.

Schulz R., Piotrowski A., Urbański K., 2007a. Mapa geologiczna kraju związkowego Brandenburgia 1:50 000, arkusz L3752 Frankfurt (Oder)/Słubice. LBGR, LGB, Cottbus.

Schulz R., Piotrowski A., Urbański K., 2007b. Mapa geologiczna kraju związkowego Brandenburgia 1:50 000, arkusz L3552 Seelow/Kostrzyn nad Odrą. LBGR, LGB, Cottbus.

Schulz W., 1973. Rhombenporphyr-Geschiebe und deren östliche Verbreitungsgrenze im nordeuropäischen Vereisungsgebiet. Zeitschrift für geologische Wissenschaften 1(9): 1141-1154.

Schulz W., 2003. Geologischer Führer für den norddeutschen Geschiebesammler. CW Verlagsgruppe Schwerin.

Skompski S., 1981. Stratygrafia osadów czwartorzędowych Ziemi Lubuskiej. Biuletyn Instytutu Geologicznego 321: 151-163.

Smed P., 1993. Indicator studies: a critical review and a new datapresentation method. Bulletin of the Geological Society of Denmark 40: 332-340.

Smed P., 2002. Steine aus dem Norden. Geschiebe als Zeugen der Eiszeit in Norddeutschland. Gebrüder Borntraeger. Berlin, Stuttgart.

Stokes C.R., Clark C.D., 2001. Palaeo-ice streams. Quaternary Science Reviews 20: 1437-1457.

Sztromwasser E., 2003. Objaśnienia do Szczegółowej mapy geologicznej Polski 1:50 000, arkusz Krosno Odrzańskie (536). PIG, Warszawa.

Sztromwasser E., 2005. Objaśnienia do Szczegółowej mapy geologicznej Polski 1:50 000, arkusz Torzym (500). PIG, Warszawa. 
Thieke H.U., Kowalski S., 2007. Objaśnienia do Mapy Geologicznej 1:50 000, arkusz L3752 Frankfurt (Oder)/Słubice. LBGR, LGB, Potsdam.

Thieke H.U., Schlaak N., Kowalski S., Urbański K., 2008. Objaśnienia do Mapy Geologicznej 1:50 000, arkusz L3552 Seelow/ Kostrzyn nad Odrą. LBGR, LGB, Potsdam.

Trela W., 2004. Objaśnienia do Szczegółowej mapy geologicznej Polski 1:50 000, arkusz Bledzew (427). PIG, Warszawa.

Urbański K., 2005a. Objaśnienia do Szczegółowej mapy geologicznej Polski 1:50 000, arkusz Rzepin (463). PIG, Warszawa.

Urbański K., 2005b. Objaśnienia do Szczegółowej mapy geologicznej Polski 1:50 000, arkusz Słubice n. Odrą (462). PIG, Warszawa.

Urbański K., 2007. Litostratygrafia glin zwałowych na obszarze Wysoczyzny Lubuskiej (Polska zachodnia). Acta Universitatis
Wratislaviensis, 3009. Prace Geologiczno-Mineralogiczne 76: 55-79.

Vinx R., 1993. Hochauflösende Rekonstruktion von Eistransportwegen: Die "Leitserienmethode". Archiv für Geschiebekunde 1(11): 625-640.

Winnicki J., 2004. Objaśnienia do Szczegółowej mapy geologicznej Polski 1:50 000, arkusz Sulęcin (464). PIG, Warszawa.

Zandstra J.G., 1999. Platenatlas van noordelijke kristalijne gidsgesteenten. Backhuys Publishers, Leiden.

Zieliński T., 1992. Moreny czołowe Polski północno-wschodniej - osady i warunki sedymentacji. Prace Naukowe Uniwersytetu Śląskiego, Katowice 1325: 1-95.

Żynda S., 1967. Geomorfologia przedpola moreny czołowej stadiału poznańskiego na obszarze Wysoczyzny Lubuskiej. Prace Komisji Geograficzno-Geologicznej Wydziału Matematyczno-Przyrodniczego PTPN 8(1): 1-191. 